\title{
Desulfurization and Denitrification Technologies of Coal-fired Flue Gas
}

\author{
Gan Cheng*, Chuanxiang Zhang \\ College of Chemistry and Chemical Engineering, Henan Polytechnic University, \\ Jiaozuo 454003, Henan Province
}

Received: 6 June 2017

Accepted: 18 July 2017

\begin{abstract}
Coal, as one of the most important sources of energy around the world due to the intensity of its exploiting and utilization, causes increasingly serious ecological problems, especially air pollution. Large amounts of pollutants are emitted during coal combustion, with $\mathrm{NO}_{\mathrm{x}}$ and $\mathrm{SO}_{2}$ being the principal compositions. Therefore, desulfurization and denitrification are extremely urgent. Many technologies have been developed and applied. Our paper introduces mature and new flue gas denitration and desulfurization technologies along with their processing principles, industrial status, merits, and demerits. The combination of SNCR and SCR technology avoids their respective shortcomings and improves denitrification efficiency and economy. Based on the present situation, future trends are put forward. Synergetic, effective, and cheap desulfurization and denitration technologies will be our focus.
\end{abstract}

Keywords: flue gas, desulfurization, denitrification, adsorption, coal

\section{Introduction}

According to the British Petroleum Statistical Review of World Energy 2015, coal's share in global primary fuel consumption increased to $30 \%$ in 2014 , and coal consumption in China accounts for more than half of global coal consumption. In China, about 396.5 Mt coal was consumed in 2015, of which $46.38 \%$ was used to generate electricity [1]. Large amounts of pollutants were emitted during coal combustion, among which acid gases ( $\mathrm{NO}_{\mathrm{x}}$ for $\mathrm{NO}, \mathrm{NO}_{2}, \mathrm{~N}_{2} \mathrm{O}_{4}, \ldots$ and $\mathrm{SO}_{\mathrm{x}}$ for $\mathrm{SO}_{2}$ and $\mathrm{SO}_{3} \ldots$ ), metals ( $\mathrm{Hg}, \mathrm{Fe} . .$.$) , and various dusts (arsenic...) have$ caused serious damage to the ecological environment and human health. In China, $22 \mathrm{Mt} \mathrm{SO}_{2}$ and $24 \mathrm{Mt} \mathrm{NO}_{\mathrm{x}}$ were emitted in 2011, while the environmental capacity for $\mathrm{SO}_{2}$ and $\mathrm{NO}_{\mathrm{x}}$ is $12-18 \mathrm{Mt}$ and less than $12 \mathrm{Mt}$, respectively. In

*e-mail: chenggan464@126.com
2012 , direct pollutant emissions from coal consumption contributed $51 \%, 66 \%$, and $52 \%$ to national PM 2.5, $\mathrm{SO}_{2}$, and $\mathrm{NO}_{2}$, respectively [2].

Therefore, it is important to remove nitrogenous and sulfide compounds from flue gas systems [3]. At present, countries around the world have invested a lot of manpower and material resources in developing a series of flue gas purification technologies that compete in desulfurization and denitrification aspects such as wet, dry, semi-dry desulfurization, denitrificationselective catalytic reduction (SCR), and activated carbon adsorption, electron beam radiation, corona, wet desulfurization denitration technology, etc. Up to now, wet flue gas desulfurization (wet-FGD) for $\mathrm{SO}_{2}$ reduction and selective catalytic reduction (SCR) for $\mathrm{NOx}$ reduction are the most widely used. Regretfully, they are expensive and complicated to simultaneously remove $\mathrm{SO}_{2}$ and $\mathrm{NO}_{x}$. As a result, cost-effective methods that can simultaneously remove both pollutants need to be developed [4]. 
Countries around the world value pollution control. On 1 January 2012 the Ministry of Environmental Protection and General Administration of Quality Supervision, Inspection, and Quarantine of the People's Republic of China issued "Emission standard of air pollutants for thermal power plants" (GB13223-2011), which stipulates stricter emissions standards for $\mathrm{SO}_{2}, \mathrm{NO}_{x}$, and other pollutants. Since 1 January 2012, for new thermal power projects the $\mathrm{SO}_{2}$ emission limit has been $100 \mathrm{mg} / \mathrm{m}^{3}$ and $\mathrm{NO}_{\mathrm{x}}$ emission limit $100 \mathrm{mg} / \mathrm{m}^{3}$, and since 1 July 2014 the $\mathrm{SO}_{2}$ emission limit has been under $200 \mathrm{mg} / \mathrm{m}^{3}$ and $\mathrm{NO}_{\mathrm{x}}$ less than $100 \mathrm{mg} / \mathrm{m}^{3}[5]$.

\section{Influence of $\mathrm{NO}_{x}$ and $\mathrm{SO}_{2}$}

$\mathrm{SO}_{2}$ and $\mathrm{NO}_{x}$ are the two main gaseous pollutants emitted from fossil fuel combustion. Apart from the direct damages caused by $\mathrm{SO}_{2}$ and $\mathrm{NO}_{x}$, the secondary pollutants derived from $\mathrm{SO}_{2}$ and $\mathrm{NO}_{x}-$ such as $\mathrm{H}_{2} \mathrm{SO}_{4}$, $\mathrm{HNO}_{3}, \mathrm{O}_{3}$, and fine particles (PM2.5) - are also harmful to both humans and the natural environment. For example, $\mathrm{NO}_{x}$ and $\mathrm{SO}_{2}$ gases were the precursors of PM2.5 via homogeneous and heterogeneous reactions, therefore playing important roles in the formation of haze. $\mathrm{SO}_{2}$ and $\mathrm{NO}_{\mathrm{x}}$ also cause acid rain, smog, ozone layer destruction, inhibition of cell growth in some microalgal species [6], and so on.

$\mathrm{NO}_{x}$ is known as a major reactant during the formation of photochemical smog, which has caused a severe impact on air quality and human health. Nitric oxide (NO) is one of the major $\mathrm{NO}_{\mathrm{x}}$ pollutants, accounting for $90 \%$ of total $\mathrm{NO}_{\mathrm{x}}$ in coal-fired flue gas. $\mathrm{NO}$ can be oxidized to $\mathrm{NO}_{2}$ in air, leading to the formation of acid rain and photochemical smog when interacting with the poly-aromatic hydrocarbons (PAHs) in the atmosphere. $\mathrm{NO}_{\mathrm{x}}$ can also make acetate fiber, cotton yarn, rayon, and other fabrics fade. The release of excessive nitrogen into aquatic systems leads to acidification and eutrophication problems. Excessive nitrogen can also impair the survival of aquatic plants and other organisms [7].

$\mathrm{SO}_{2}$ is a pungent, toxic, colorless gas, and its effects on human health vary with concentrations of $\mathrm{SO}_{2}$ [8]. Low concentrations of $\mathrm{SO}_{2}$ may cause respiratory tract luminal narrowing, faster breathing, and respiratory-reducing activity; high concentrations of $\mathrm{SO}_{2}$ may cause coughing, sneezing, respiratory irritation, and other symptoms, and more seriously pneumonectasis and even death. Acid mist will corrode metal or building surfaces. The aerosols generated by chemical reactions of $\mathrm{SO}_{2}$ cause more serious harm than simple $\mathrm{SO}_{2}$ gas. Sulfur dioxide $\left(\mathrm{SO}_{2}\right)$ waste released from fossil fuel combustion has been commonly accepted as the main cause of acid rain, which has caused considerable concern in past decades because of its extent harm to the global environment.

\section{Denitration Technology}

The abatement technologies of $\mathrm{NO}_{\mathrm{x}}$ emissions can be generally classified into three categories: pre-combustion control, low-nitrogen combustion technologies, and post-combustion control. Both pre-combustion and combustion controls have been used, but only to achieve a low removal efficiency, usually less than 50\% [9]. To achieve high $\mathrm{NO}_{\mathrm{x}}$ reduction, post-combustion control needs to be implemented.

The efficiency of flue gas denitrification technology is higher than that of low-nitrogen combustion technology. The flue gas denitrification methods mainly include oxidation or reduction, and the reduction method is more often applied. The principle of the reduction method is to convert $\mathrm{NO}_{\mathrm{x}}$ to $\mathrm{N}_{2}$ in the following simplified order: $\mathrm{NO}_{3}{ }^{-} \rightarrow \mathrm{NO}_{2}{ }^{-} \rightarrow \mathrm{NO} \rightarrow \mathrm{N}_{2} \mathrm{O} \rightarrow \mathrm{N}_{2}[10]$.

Commercially available post-combustion technologies include calcium-based flue gas denitrification, selective non-catalytic reduction (SNCR), and selective catalytic reduction (SCR). The catalysts for the $\mathrm{NH}_{3}-\mathrm{SCR}$ process are normally metal or metal oxides supported on $\mathrm{SiO}_{2}$, $\mathrm{TiO}_{2}$, carbon-based materials, and zeolites [11].

\section{Selective Catalytic Reduction (SCR)}

SCR denitration technology is one of the mainstream technologies in the world, and it has been applied to more than 500 pieces of industrialized equipment. The reactioN temperature is below $500^{\circ} \mathrm{C}$; ammonia, urea, or hydrocarbon are used as reducing agents; and $\mathrm{NO}_{\mathrm{x}}$ in flue gas is converted into $\mathrm{N}_{2}$ and water. Moreover, reducing agent reacts with $\mathrm{NO}_{\mathrm{x}}$ and basically does not react with $\mathrm{O}_{2} \cdot \mathrm{NH}_{3}-\mathrm{SCR}$ technology also is relatively mature and reliable, and the reactions are as follows [12]:

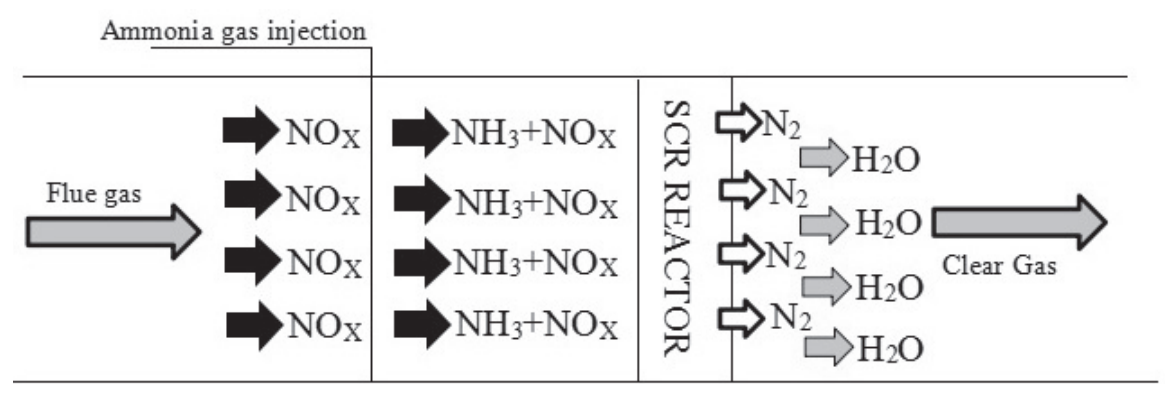

Fig. 1. Reaction principle diagram of SCR. 


$$
\begin{gathered}
4 \mathrm{NO}+4 \mathrm{NH}_{3}+\mathrm{O}_{2} \rightarrow 4 \mathrm{~N}_{2}+6 \mathrm{H}_{2} \mathrm{O} \\
6 \mathrm{NO}+4 \mathrm{NH}_{3} \rightarrow 5 \mathrm{~N}_{2}+6 \mathrm{H}_{2} \mathrm{O} \\
2 \mathrm{NO}_{2}+4 \mathrm{NH}_{3}+\mathrm{O}_{2} \rightarrow 3 \mathrm{~N}_{2}+6 \mathrm{H}_{2} \mathrm{O} \\
6 \mathrm{NO}_{2}+8 \mathrm{NH}_{3} \rightarrow 7 \mathrm{~N}_{2}+12 \mathrm{H}_{2} \mathrm{O}
\end{gathered}
$$

Most of the $\mathrm{NO}_{\mathrm{x}}$ in the flue gas existed as NO. Therefore, the reaction is mainly in reaction (1) and (2). The reaction principle is shown in Fig. 1.

SCR technology was first applied in Japan's Shimoneski power plant in 1975, and from there expanded to Europe, the United States, and other developed countries and regions [13].

The method has such characteristics as high air purification rate $(>90 \%)$, low reaction temperature $\left(300-400^{\circ} \mathrm{C}\right)$, compact processing equipment, and reliable operation. Currently it is thought of as the best stationary source denitration technology, but the investment in processing equipment is large and there are such problems as ammonia slip and equipment corrosion.

\section{Selective Noncatalytic Reduction-SCNR}

SNCR technology was proposed by R. K. Lyon of the United States in 1975 for removing $\mathrm{NO}_{\mathrm{x}}$. SNCR is also called thermal denitration. The reducing agents that contain $\mathrm{NH}_{\mathrm{x}}$ (for example ammonia and urea) is injected into the furnace and broken down rapidly under temperatures between 900 and $1,100^{\circ} \mathrm{C}$. The $\mathrm{NH}_{3}$ produced and $\mathrm{NO}_{\mathrm{X}}$ carry out selective reaction and $\mathrm{N}_{2}$ is produced. When the temperature is below $900^{\circ} \mathrm{C}$, the reaction of $\mathrm{NH}_{3}$ is not complete, causing ammonia slip; when the temperature is higher than $1,100^{\circ} \mathrm{C}, \mathrm{NH}_{3}$ will be oxidized into NO. If the temperature is too high, the amount of $\mathrm{NO}$ oxidized from $\mathrm{NH}_{3}$ will increase, leading to the increase of $\mathrm{NO}_{\mathrm{x}}$ concentration and the decrease of conversion ratio.

SNCR technology is one relatively mature flue gas denitration technology that has been put into commercial operation. In the mid-1970s, SNCR was first applied in Japanese gas-fuel power plants, and was gradually extended to Europe, the United States, and other countries. Currently there are about 300 pieces of industrialized SNCR equipment in the world [14].

SNCR technology is suitable for medium equipment upgrading. There are many advantages such as little investment, low cost, short construction cycle, and without a catalyst. However, ammonia escape rate is high, denitration efficiency is low $(50-60 \%)$, and the temperature requirement is rigorous.

\section{SCR/SNCR Synergic Denitrification Technology}

SNCR and SCR are the most commonly used denitrification technologies [15]. However, the SNCR technology operates at very high temperatures. It has been reported that $\mathrm{SCR}$ by $\mathrm{NH}_{3}$ and $\mathrm{CuO} / \mathrm{Al}_{2} \mathrm{O}_{3}$-based catalysts is the most effective technology for NO removal, but require higher capital and operating costs. Currently few large-scale pieces of equipment have adopted SNCR technology solely, and most of them combine SNCR and SCR technology, which effectively combines the low cost of SNCR technology with the high-efficiency denitration ratio and low ammonia escape of SCR technology. Denitrification efficiencY is more than $80 \%$.

\section{Biological Technology}

Compared to conventional end-of-pipe controls of $\mathrm{NO}_{\mathrm{x}}$, such as chemical reduction and adsorption, biological $\mathrm{NO}_{\mathrm{x}}$ removal is an alternative, cost-effective, and environmentally sustainable technology [16]. However, biological removal efficiency is restricted by the low solubility of $\mathrm{NO}$ in the water, which directly influences retention time.

Currently biological denitration technology is still at the initial stage of research. On the one hand, there are difficulties in the denitration microorganism cultivation and industrial application; on the other hand, NO is the major constituent of $\mathrm{NO}_{\mathrm{x}}$ in flue gas and is basically insoluble in water so that it cannot be converted by the microorganism in the liquid; besides, the microorganism has a low ability to absorb NO, leading to a low practical purification rate of $\mathrm{NO}_{x}$.

In the future, the research focus is to strengthen breeding of efficient and inexpensive bacterium, and the developed relative amplification technology.

\section{Microwave Denitration}

Broadly speaking, microwave radiation refers to electromagnetic radiation in the frequency range from $300 \mathrm{MHz}$ to $300 \mathrm{GHz}(\lambda=1 \mathrm{~mm}$ to $100 \mathrm{~cm})$. Microwaveaided catalytic decomposition technology utilizes catalysts such as activated carbon and zeolite to decompose $\mathrm{NO}_{\mathrm{x}}$ to $\mathrm{N}_{2}$ and $\mathrm{CO}_{2}$, or water directly with the help of a microwave. NO decomposition temperature decreased greatly [17].

Currently, research on microwave denitration is still at the initial stage. Although $\mathrm{NO}_{\mathrm{x}}$ removal rate is high, such problems as high energy consumption, high equipment fees, and shielding prevention are difficult to resolve.

\section{Desulfurization Technology}

There are three methods of coal-fired desulfurization at present, namely desulfurization before combustion, during combustion, and after combustion (namely flue gas desulfurization) [18-20]. In contrast, flue gas desulfurization technology is economical and highly efficient. Removal of $\mathrm{SO}_{2}$ from the flue gas emitted during combustion of fossil fuels has been the focus of research worldwide since the 1970s. At present, various technologies have been exploited for $\mathrm{SO}_{2}$ treatment. Based on the amount of water consumption, they can 
be classified as dry desulfurization (DFGD), semidry desulfurization (SDFGD), and wet desulfurization (WFGD) techniques.

DFGD use granular or powder adsorbents such as activated carbons, activated carbon fibres, and metal oxides to retain $\mathrm{SO}_{2}$ in their fine pores via physical adsorption, or catalyze $\mathrm{SO}_{2}$ to other sulfides through chemical adsorption. $\mathrm{SO}_{2}$ removal efficiency of SDFGD depends on the adopted methods such as spray dry, fluidized-bed, etc. Although both DFGD and SDFGD could run with a small space and low capital requirement, desulfurization efficiency is relatively poor (75-90\%). Currently, WFGD is the most widely used technology due to its higher efficiency $(\geq 95 \%)$ and better operating stability. However, alkaline absorbents or organic solvents are inevitably used in the WFGD, leading to an undesired secondary pollution and resource waste resulting from adsorbent regeneration and by-products [21].

\section{Wet Desulfurization Technology}

Among the existing flue gas desulphurization technologies, wet desulfurization accounts for about $85 \%$, with Japan (98\%), the USA (92\%), and Germany $(90 \%)$ being the main users, all of which are developed.

The dual-alkali flue gas desulfurization (FGD) system is a popular process for $\mathrm{SO}_{2}$ treatment. Flue gas contacts with a $\mathrm{NaOH}$ (or $\mathrm{Na}_{2} \mathrm{CO}_{3}$ ) absorbent, and the absorbent then reacts with lime, which is used as a regeneration agent to produce calcium sulfate (gypsum) and sodium hydroxide as byproducts. The main reactions are listed below. Scaling and blocking are avoided because the reaction is performed between the liquid and gas phases and because the system has a high desulfurization performance. Gypsum has a poor quality because of the existence of ash and $\mathrm{Na}_{2} \mathrm{SO}_{4}$, a byproduct of desulfurization. Gypsum is hence generally discarded because its use results in a bulk of industrial solid wastes that trigger environmental concerns. Thus, new processes must be explored to avoid gypsum production [22].

Nevertheless, the byproducts from the wet FGD process such as gypsum, magnesium sulfate, or ammonia sulfate have become a big burden because of their poor market.

The seawater flue gas desulfurization (FGD) process is a kind of wet FGD technology [23]. It takes advantages of inherent alkalinity of seawater to absorb and neutralize sulfur dioxide inexhaust gases. In a power plant application, seawater is obtained from the condenser outlet of a steam turbine, and the acidic effluent of the scrubber is treated with air to reduce its chemical oxygen demand (COD) and acidity before it is discharged. The main commercialized SWFGD processes are Norway ABB, Lentjes Bischoff (Germany), and Fujikasui (Japan). In ABB's seawater scrubbing process (the Flakt-Hydro process), an adsorption tower was filled with patented random packing. The packings provided high specific surface area to improve the interaction of flue gas and seawater, and the desulfurization efficiency was determined by the adsorption equilibrium of liquid and gas. The $\mathrm{SO}_{2}$ removal efficiency would be greatly improved when catalytic packing was loaded, and about $5 \mathrm{vol} \%$ oxygen in flue gases was used as oxidant for S(IV) to $\mathrm{S}(\mathrm{VI})$; the latter has higher solubility.

$\mathrm{FeSO}_{4}$ solution was also used as an absorbent for $\mathrm{SO}_{2}$ removal, and PFS (polymeric ferric sulfate) was obtained as a byproduct [24]. Sodium chlorate was added to oxidize $\mathrm{Fe}^{2+}$ to $\mathrm{Fe}^{3+}$ and $\mathrm{SO}_{2}$ to $\mathrm{H}_{2} \mathrm{SO}_{4}$. In the presence of oxygen, iron ions may play a role in the catalytic oxidation of $\mathrm{SO}_{2}$. A PFS solution was obtained through hydroxylation and polymerization of $\mathrm{Fe}^{3+}$, and solid PFS was then obtained by spray drying.

\section{Dry Desulfurization Technology}

Dry FGD technologies, in which $\mathrm{SO}_{2}$-containing flue gases contact with dry sorbents (lime or limestone), are considered to be more suitable for flue gas desulfurization due to their low operating costs, high desulfurization efficiency, and no water consumption. Besides, dry FGD processes are operated at elevated temperatures. As a result, the wastes produced by dry FGD processes are easier to dispose of than those from wet FGD processes.

Manganese oxides $\left(\mathrm{MnO}_{\mathrm{x}}\right)$ have received special emphasis as an absorbent for sulfur dioxide recovery [25]. Both mineral slurry and dry manganese oxides (ores) have been shown to be effective sorbents for sulfur compound removal. In the leaching of manganese ores, sulfur dioxide is shown to be a rapid, effective, and sensitive reductant for manganese oxide minerals. However, the formation of dithionate may bring pollution to the follow-up processes. During the absorbing process, $\mathrm{SO}_{2}$ in the waste gases reacts with the manganese oxide and results in the formation of manganese sulfate, which is then treated to regenerate back to the manganese oxide. By means of the above processes, $\mathrm{SO}_{2}$ is removed from the waste gases without cooling, hence avoiding the undesirable problems of cooling referred to above.

Apart from the conventional FGD technologies, electrochemical ones (EFGD) offer an alternative way for control of $\mathrm{SO}_{2}$ pollution where electrons act as a clean reagent of pollutant treatment. EFGD has attracted much attention owing to its superiority in desulfurization efficiency as well as environmental friendliness [26].

At present, the lignite-based desulfurization agent mainly includes lignite itself, semi-coke [27], carbon materials (including modified carbon materials), humic acid, and so on. Among them, the carbon material is most widely used.

Hao et al. [28] prepared a complex absorbent (CA) of $\mathrm{HA}-\mathrm{Na} / \mathrm{NaClO}_{2}$ for simultaneous removal of $\mathrm{SO}_{2}$ and NO. The effects of various factors were assessed, such as reaction temperature, $\mathrm{CA} \mathrm{pH}$, the coexistence gases, and the soluble anions. The results indicated that the desulfurization efficiencies were $98-99.8 \%$ and the concentration could be controlled below $35 \mathrm{mg} / \mathrm{m}^{3}$. NO conversion efficiency could reach approximately $98 \%$. Efthimiadou et al. [29] adopted northern Greece lignite 
(calcium carbonate content up to $40 \%$ ) to remove the $\mathrm{SO}_{2}$ of coal-fired fluge gas, the desulfurization efficiency is over $80 \%$ and $\mathrm{SO}_{2}$ emission concentrations is under $1 \mathrm{mg} / \mathrm{Nm}^{3}$. In the $1980 \mathrm{~s}$, Green of the United States [30] used humic acid-mixed ash to absorb $\mathrm{SO}_{2}$ in flue gas. Ash was first dissolved in humic acid solution and the humic acid salt solution was alkaline, so $\mathrm{SO}_{2}$ can be absorbed effectively.

\section{Semi-Dry Desulfurization Technology}

Semi-dry flue gas desulfurization technology is when $\mathrm{SO}_{2}$ is absorbed by wet absorbent and dry powdered product is obtained with the action of hot flue gas. Although the method generates less pollution and its cost is relatively low, the efficiency and utilization rates are not high; it is suitable for flue gas with low sulfur content. At present, spray dryer absorber (SDA), LIMESTONE INJECTION INTO THE FURNACE AND ACTIVATION OF CALCIUM (LIFAC), circulating fluidized bed (CFB), and new integrated desulfurization (NID) have been widely applied.

Among them, for the control of $\mathrm{SO}_{2}$ in flue gas, the most mature and widely used technique is wet limestone/ gypsum flue gas desulfurization (FGD); for the $\mathrm{NO}_{x}$, selective catalytic reduction process denitration (SCR) is mainly used. However, the individual pollutant treatment system has the disadvantages of a complex treatment process, large installation space, and high investment and operating cost. Thus, the multi-pollutants simultaneous removal technologies for coal-fired power plants have become a hot research issue in recent years [31].

\section{Simultaneous Desulfurization and Denitration Technology}

Currently, amounts of technologies for simultaneous $\mathrm{NO}_{\mathrm{X}}$ and $\mathrm{SO}_{2}$ removal, such as adsorbent adsorption, non-thermal plasma (NTP), and plasma removal, have been developed and applied in past decades due to great advantages in the simultaneous removal of multiple pollutants.

During the desulfurization and denitration processes, the catalyst is of the essence because of their low cost and high efficiency [32]. The catalysts include $\mathrm{MoS}_{2}, \mathrm{CuO}-\mathrm{CeO}_{2}$, Ce-Ti, copper, and iron oxide catalysts. Extensive research has been undertaken using hydrocarbons $\left(\mathrm{CH}_{4}, \mathrm{C}_{3} \mathrm{H}_{8}, \mathrm{C}_{3} \mathrm{H}_{6}\right)$, alcohols $\left(\mathrm{CH}_{3} \mathrm{OH}, \mathrm{CH}_{3} \mathrm{CH}_{2} \mathrm{OH}\right)$, and ammonia as reductants for denitrification over various catalytic materials such as $\mathrm{Al}_{2} \mathrm{O}_{3}, \mathrm{ZrO}_{2}, \mathrm{CuO}, \mathrm{TiO}_{2}$, and zeolite. The zeolite catalyst, which reduced the nitrogen oxide selectively with the hydrocarbon as a reducing agent under the rich oxygen condition, was developed. Simultaneous $\mathrm{SO}_{2}$ and $\mathrm{NO}_{x}$ removal from stationary sources could be achieved with high efficiency using copper on alumina catalyst sorbents $\left(\mathrm{CuO} / \mathrm{Al}_{2} \mathrm{O}_{3}\right)$, or using a dual bed of potassiumcontaining coal-pellets and calcium-containing pellets.
Adsorption Technology

\section{Carbon-Based Material Adsorption}

Such adsorbents as heteropoly acid, molecular sieve, activated carbon [33], activated coke, natural zeolite, silica gel, and peat containing $\mathrm{NH}_{3}$ can absorb and remove $\mathrm{NO}_{\mathrm{X}}$ and $\mathrm{SO}_{2}$ simultaneously, in which case some adsorbents such as silica gel, molecular sieve, activated carbon, and activated coke also have catalytic performance. The removal of $\mathrm{SO}_{2}$ makes use of the microporous catalytic absorption of activated coke to produce sulfuric acid stored in the micropore of activated coke and then reproduce by heat. Activated coke can catalyze and oxidize the $\mathrm{NO}$ in flue gas to $\mathrm{NO}_{2}$. The desorbed $\mathrm{NO}_{2}$ can be recycled by water or alkali absorption or, in the condition of ammonification, reduce NO to water and N through catalysis, and then they are discharged into the atmosphere. At present, the technology has been applied in Germany, Japan, and other countries. Mitsui-BF technology has been successfully applied in Germany's Arzberg and Hoschst coal-fired power plants in 1987 and 1989, respectively. The activated carbon moving bed was installed by Japan Electric Power Company in 1995. When the molar ratio of $\mathrm{NH}_{3} / \mathrm{NO}_{\mathrm{x}}$ is 0.85 , the removal rate of $\mathrm{NO}_{x}$ came up to $80 \%$ [34].

Activated carbon fiber (ACF) is a new high efficiency multifunctional adsorption material with a large specific surface area, small pore size, high adsorption rate, and large adsorption capacity, and is easily recycled. It has become a hot material in the research of desulfurization and denitrification in recent years.

Activated coke desulfurization is because of the adsorption and catalytic oxidation of $\mathrm{SO}_{2}$ on the coke surface. With no oxygen and water vapor existing in the flue gas, the adsorption of $\mathrm{SO}_{2}$ by activated carbon only belongs to physical adsorption, and the adsorption capacity is weak; when oxygen and water vapor exist in the flue gas, because of the catalysis action of the active coke surface, physical and chemical adsorption occur simultaneously. $\mathrm{SO}_{2}$ is oxidated as $\mathrm{SO}_{3}$ and $\mathrm{SO}_{3}$ reacts with water vapor to form sulfuric acid so that the adsorption capacity greatly increases [35].

When $\mathrm{O}_{2}$ and water vapor are present in the flue gas, the reaction process is:

$$
2 \mathrm{SO}_{2}+2 \mathrm{H}_{2} \mathrm{O}+\mathrm{O}_{2} \stackrel{\text { Activated coke }}{\longrightarrow} 2 \mathrm{H}_{2} \mathrm{SO}_{4}
$$

When ammonia is added into the activated coke desulfurization system, $\mathrm{NO}$ is also removed simultaneously:

$$
4 \mathrm{NO}+4 \mathrm{NH}_{3}+\mathrm{O}_{2} \longrightarrow 4 \mathrm{~N}_{2}+6 \mathrm{H}_{2} \mathrm{O}
$$

$\mathrm{TiO}_{2}$ is a kind of excellent photocatalysis material that has the characteristics of non-toxicity, high photocatalytic activity, high stability, strong oxidation ability, low 
energy consumption, and reusability. Li et al. [36] proved that ACF modified with $\mathrm{TiO}_{2} / \mathrm{Cu}_{2} \mathrm{O}$ composite catalyst can remove $\mathrm{SO}_{2}$ and $\mathrm{NO}$. The highest desulfurization and denitrification efficiencies are $90 \%$ and $60 \%$ at $40^{\circ} \mathrm{C}$ under visible light. The pore size of ACF is decreased after being modified by $\mathrm{TiO}_{2} / \mathrm{Cu}_{2} \mathrm{O}$. The surface functional groups including graphite carbon and carbonyl group are increased, which enhance the $\mathrm{NO}$ and $\mathrm{SO}_{2}$ adsorption capacities of ACF.

\section{Oxidant Oxidation Absorption}

Currently, commonly used oxidizing agents include $\mathrm{ClO}_{2}, \mathrm{Na}_{2} \mathrm{~S}_{2} \mathrm{O}_{8}, \mathrm{O}_{3}, \mathrm{KMnO}_{4}, \mathrm{H}_{2} \mathrm{O}_{2}, \mathrm{NaClO}_{2}, \mathrm{NaClO}$, and so on. For the wet FGD, the reaction mainly occurs in the liquid phase, so $\mathrm{ClO}_{2}, \mathrm{O}_{3}$, etc. will not be taken into consideration. $\mathrm{KMnO}_{4}$ and $\mathrm{H}_{2} \mathrm{O}_{2}$ could be effective for simultaneous absorption of $\mathrm{SO}_{2}$ and $\mathrm{NO}_{\mathrm{x}}$ in alkaline conditions, and the removal effects improve with the increase of $\mathrm{pH}$. However, if the $\mathrm{pH}$ of actual desulfurization slurry is between 5 and $7, \mathrm{KMnO}_{4}, \mathrm{H}_{2} \mathrm{O}_{2}$ will not be primarily considered. Moreover, the reaction products of $\mathrm{KMnO}_{4}$ may contaminate the FGD gypsum and causing secondary pollution. And the chemical performance of $\mathrm{H}_{2} \mathrm{O}_{2}$ is unstable, so it is difficult to be transported for long distance and reserved for a long time. In general, $\mathrm{NaClO}_{2}$ is the oxidizing agent and its effect is great for simultaneous desulfurization and denitrification [37].

Liémans et al. [38] proposed adopting aqueous acidic solutions containing hydrogen peroxide to oxidize $\mathrm{NO}_{\mathrm{x}}$ and $\mathrm{SO}_{2}$ to $\mathrm{HNO}_{3}$ and $\mathrm{H}_{2} \mathrm{SO}_{4}$. Absorption tests were achieved at $20^{\circ} \mathrm{C}$ and atmospheric pressure in a cables-bundle contactor; a range of partial pressures (600-2,000 ppm $\mathrm{SO}_{2}, 5,000$ ppm $\left.\mathrm{NO}_{\mathrm{x}}\right)$ and liquid phase concentrations (0-4 mol/l for each acid, $0-1 \mathrm{~mol} / \mathrm{l}$ for $\mathrm{H}_{2} \mathrm{O}_{2}$ ). While the presence of acids, especially $\mathrm{H}_{2} \mathrm{SO}_{4}$, has a negative effect on $\mathrm{SO}_{2}$ absorption rates, more acidic conditions were found to promote global $\mathrm{NO}_{\mathrm{x}}$ absorption. Compared to the use of classical alkaline conditions leading to slightly higher $\mathrm{SO}_{\mathrm{x}}$ and $\mathrm{NO}_{\mathrm{x}}$ absorption efficiencies, acid solutions allow us to avoid the undesired absorption of $\mathrm{CO}_{2}$ and the extra-consumption of the reactant.

Wang et al. [39] used $\mathrm{NaClO}_{2} / \mathrm{NaOH}$ solution as the absorbent to study the removal efficiency of $\mathrm{SO}_{2}$ and $\mathrm{NO}_{x}$ under various operating parameters such as $\mathrm{NaClO}_{2}$ concentration $\left(m_{\mathrm{s}}\right), \mathrm{NaClO}$ concentration $\left(m_{\mathrm{p}}\right)$, molar ratio of $\mathrm{NaClO}_{2} / \mathrm{NaClO}(M)$, solution temperature $\left(T_{\mathrm{R}}\right)$, initial solution $\mathrm{pH}$, gas flow $\left(V_{\mathrm{g}}\right)$, and inlet concentration of $\mathrm{SO}_{2}$ $\left(C_{\mathrm{S}}\right)$ and NO $\left(C_{\mathrm{N}}\right)$. It was found that the initial solution $\mathrm{pH}$ and the gas flow rate were the main factors affecting simultaneous desulfurization and denitrification. The optimal experimental conditions were determined to be initial solution $\mathrm{pH}=6, T_{\mathrm{R}}=55^{\circ} \mathrm{C}$, and $M=1.3$, under which the average efficiencies of desulfurization and denitrification could reach $99.7 \%$ and $90.8 \%$, respectively.

$\mathrm{NO}$ can be oxidized by $\mathrm{O}_{3}$ into high-order nitrogen species with good $\mathrm{H}_{2} \mathrm{O}$ solubility. After oxidation by
$\mathrm{O}_{3}$, a high order nitrogen species and $\mathrm{SO}_{2}$ are able to be removed by using the WFGD system. Therefore, it is possible for simultaneous removal of $\mathrm{NO}_{x}$ and $\mathrm{SO}_{2}$ in the washing tower by pre-oxidation of NO. In the present study, $\bullet \mathrm{OH}$ radicals were generated by $\mathrm{O}_{3}$ produced from an $\mathrm{O}_{3}$ generator under the catalysis of $\mathrm{H}_{2} \mathrm{O}$ and metal oxides. And the oxidant mixtures including $\mathrm{O}_{3}, \mathrm{H}_{2} \mathrm{O}$, and - $\mathrm{OH}$ radicals were injected into the duct [40-41].

\section{Non-Thermal Plasma (NTP) Technology}

Pollutant removal of NTP [42] mainly depends on the free radical reactions. Free radicals refer to atoms, molecules, or ions that have unpaired valence electrons, and these unpaired electrons make free radicals highly chemically reactive toward other substances. NTP can be generated by gas discharge and ionizing radiation methods. For each kind of method, various electrons, free radicals, excited-state molecules and atoms, and positive and negative ions will be generated during the NTP-generated process. Non-thermal plasma can be generated by either the gas discharge method or ionizing radiation method. Different reactor structures are needed for various non-thermal plasma generating methods; meanwhile the structure parameters of a reactor have a significant effect on the characteristics of NTP and pollutant removal efficiency. Therefore, a variety of reactors for the NTP flue gas cleaning technologies have been developed.

Based on the time-scale of different chemical reactions, the chemical process of NTP can be divided into two processes. In the primary process, first collisions between high-energy electrons that are accelerated through the high voltage electric field and flue gas molecules lead to the ionization, excitation, and dissociation of neutral molecules and generate positive ions, excited-state molecules and atoms, and primary free radicals. In the secondary process, partial primary free radicals will generate secondary free radicals through the radical recombination reactions.

High energy electron radiation is used to stimulate gas molecules $\left(\mathrm{H}_{2} \mathrm{O}, \mathrm{O}_{2}\right)$ around flue gas and produce active substances such free electrons; free atoms such as $\mathrm{OH}, \mathrm{O}$, $\mathrm{HO}_{2}$, and $\mathrm{O}_{3}$ with strong oxidizability and free radicals; and $\mathrm{SO}_{2}$ and $\mathrm{NO}_{\mathrm{x}}$ are oxidized into $\mathrm{HNO}_{3}$ and $\mathrm{H}_{2} \mathrm{SO}_{4}$. In the situation that injects absorbent ammonia, the powders of sulfur ammonia and nitramine are produced. Collecting them by bag filter or electrostatic precipitator as fertilizers can reach the goal of purifying flue gas. According to the sources of high-energy electrons, they can be divided into electronic beam accelerator and the pulse corona-induced plasma chemical process.

\section{Electronic Beam Accelerator (EBA)}

Currently, EBA is one of advanced flue gas treatment technologies internationally and it makes use of a highenergy electron accelerator to produce high-energy electrons. The advantages of this method are: no 
wastewater, no waste residue, recyclable by-products, simultaneous desulfuration and denitration, and high desorption rate [43]. But EBA also has many drawbacks:

- Energy use rate is low.

- The structure of equipment is complex, the area occupied is large, and the shielding and preventation problems of $\mathrm{X}$ radiation are solved only withdifficulty.

\section{Pulse Corona-Induced Plasma Chemical Process (PPCP)}

PPCP is also called non-thermal plasma, which uses high-voltage pulse corona with thousands of volts to discharge and produce high-energy electrons $(5 \sim 20 \mathrm{eV})$. The pulse-induced plasma can improve the temperature of electrons only, but cannot improve the temperature of ions at ambient temperatures, so its energy efficiency is at least twice as high as EBA, but it removes $\mathrm{SO}_{2}$ and $\mathrm{NO}_{\mathrm{x}}$ simultaneously as well as heavy metals, and its electron energy is high, avoiding the use of an electronic accelerator [44].

It is generally thought that PPCP is one of most prospective methods of desulfurization and denitrification internationally, but the method started late and was not mature, and there are still many problems to be further studied - mainly including improving energy use rates and reducing energy consumption.

\section{Conclusions}

Except for flue gas, the technologies of desulfurization and denitrification have also been applied in municipal solid wastes, the iron and steel industry, brackish and saline water, reverse osmosis brines, acid mining wastewater, and pulp and paper industrial wastewater. Therefore, these technologies in different application fields can realize integration and mutual promotion. Based on the current status of flue gas desulfurization and denitrification - although some offer good development prospects, none can completely substitute for flue gas purification due to high costs or technical problems. Therefore, developing more effective and cheaper flue gas treatment technologies for $\mathrm{NO}_{\mathrm{X}}$ and $\mathrm{SO}_{2}$ are undoubtedly an effort we should undertake.

\section{List of Symbols and Notations}

CA Complex absorbent

CFB Circulating fluidized bed

COD Chemical oxygen demand

EBA Electronic beam accelerator

EFGD Electrochemical flue gas desulfurization

FGD Flue gas desulfurization

LIFAC Limestone injection into the furnace and activation of calcium

$\mathrm{MnO}_{\mathrm{x}} \quad$ Manganese oxides
NID New integrated desulfurization

$\mathrm{NO} \quad$ Nitrogen oxide

NTP Non-thermal plasma

PAH Poly-aromatic hydrocarbon

PFS Polymeric ferric sulfate

PPCP Pulse corona induced plasma chemical process

SCR Selective catalytic reduction

SCR Selective catalytic reduction

SDA Spray dryer absorber

SNCR Selective non-catalytic reduction

$\mathrm{SO}_{\mathrm{x}} \quad$ Sulfur oxide

$C_{\mathrm{N}} \quad$ Inlet concentration of $\mathrm{NO}$

$C_{\mathrm{S}} \quad$ Inlet concentration of $\mathrm{SO}_{2}$

$M \quad$ Molar ratio of $\mathrm{NaClO}_{2} / \mathrm{NaClO}$

$M_{\mathrm{p}} \quad \mathrm{NaClO}$ concentration

$M_{\mathrm{s}}^{\mathrm{p}} \mathrm{NaClO}_{2}$ concentration

$T_{\mathrm{R}} \quad$ Solution temperature

$V \quad$ Gas flow

$\lambda^{\mathrm{g}} \quad$ Wave length

ACF Activated carbon fiber

\section{Acknowledgements}

Our thanks for support from the National Nature Science Foundation of China (grant No. 51604097), China Postdoctoral Science Foundation (grant No. 2016M602240), the Henan Postdoctoral Science Foundation (grant No. 172524), and Doctoral Foundation of Henan Polytechnic University (grant No. B2015-13).

\section{References}

1. KUMAR S., VENUGOPAL R. Performance analysis of jig for coal cleaning using 3D response surface methodology. Int J Min Sci Techno 27, 333, 2017.

2. SHI W.X., LIN C., CHEN W., HONG J.L., CHANG J.C., DONG Y., ZHANG Y.L. Environmental effect of current desulfurization technology on fly dust emission in China. Renew Sust Energ Rev 72, 1, 2017.

3. GUO Q., HUA H.Y., SHI Z.J., YANG C.C., LI P., HUANG M., NI W.M., SHI M.L., JIN R.C. Towards simultaneously removing nitrogen and sulfur by a novel process: Anammox and autotrophic desulfurization-denitrification (AADD). Chem Eng J 297, 207, 2016.

4. YE J.H., SHANG J., LI Q., XU W.W., LIU J., FENG X., ZHU T. The use of vacuum ultraviolet irradiation to oxidize $\mathrm{SO}_{2}$ and $\mathrm{NO}_{x}$ for simultaneous desulfurization and denitrification. J Hazard Mater 271, 89, 2014.

5. ZHAO Y. The Reaction Characteristics and Mechanisms of Simultaneous Removal of $\mathrm{SO}_{2}$ and $\mathrm{NO}_{x}$ by $\mathrm{MgO}$ /Additives Solution. North China Electric Power University, Beijing, China, 2014.

6. DUARTE J.H., FANKA L.S., COSTA J. Utilization of simulated flue gas containing $\mathrm{CO}_{2}, \mathrm{SO}_{2}, \mathrm{NO}$ and ash for Chlorella fusca cultivation. Bioresource Technol 214, 159, 2016.

7. CAI S.K. Research on Simultaneous Desulfurization and Denitrification by Combining Liquid-phase Oxidation with Limestone-gypsum System. Central South University, Changsha, China, 2012. 
8. CHANG G.Q., SONG C.Y., WANG L. A modeling and experimental study of flue gas desulfurization in a dense phase tower. J Hazard Mater 189, 134, 2011.

9. LI X.C., DONG Z., DOU J.X., YU J.L., TAHMASEBI A. Catalytic reduction of NO using iron oxide impregnated biomass and lignite char for flue gas treatment. Fuel Process Techno 148, 91, 2016.

10. GUO L.F., SHU Y.J., GAO J.M. Present and Future Development of Flue Gas Control Technology of DeNO_X in the World. Energy Procedia 17, 397, 2012.

11. YANG N., YU J.L., DOU J.X., TAHMASEBI A., SONG H., MOGHTADERI B., LUCAS J., WALL T. The effects of oxygen and metal oxide catalysts on the reduction reaction of $\mathrm{NO}$ with lignite char during combustion flue gas cleaning. Fuel Process Techno 152, 102, 2016.

12. YAN B.Q. Synchronization Process desulfurization and denitrification of flue gas integration technology and its application. Yangzhou University, Yangzhou, China, 2013.

13. GU W.R., ZHOU M.J., MA W. Technology status and analysis on coal-fired flue gas denitrification. Chem Ind Eng Prog 31, 2084, 2012.

14. ZHU J.W., ZHANG F., WANG H.C., WANG F., SHU Y. Analysis on Development Trend of Desulfurization and Denitration Technologies for Coal-fired Flue Gas. J Env Eng Technol 5, 200, 2015 .

15. LI R.N., LIU X. Main fundamental gas reactions in denitrification and desulfurization from flue gas by nonthermal plasmas. Chem Eng Sci 55, 2491, 2000

16. NIE M.Y. Oxidation Removal of Sulfur Dioxide and Nitric Oxide by Ozone in the Flue Gas. East China University of Science and Technology, Shanghai, China, 2012.

17. SEGAWA T., KAWAGUCHI K., ISHII K., SUZUKI M., ARIMITSU N., YOSHIDA H., FUKUI K. Nickel oxide powder synthesis from aqueous solution of nickel nitrate hexahydrate by a microwave denitration method. Adv Powder Technol 26, 983, 2015.

18. HONG Z.P., LAN J.X. Desulfurization in the reducing state and denitrification with ammonia injection in an FBC test facility. Fuel 77, 757-762, 1998

19. XIAO Y., HUANG Z.G., YANG F., LU X.G. The Dynamics of Soil Moisture and Salinity after Using Saline Water Freezing-Melting Combined with Flue Gas Desulfurization Gypsum. Pol J Environ Stud 23, 1763, 2014.

20. BURYAN P., VEJVODA J., SKÁCEL F., TEKÁČ V. Chlorine Balance at Brown Coal Combustion and Flue Gas Desulfurization. Pol J Environ Stud 17, 687, 2008.

21. ZHANG Y., WANG T., YANG H.R., ZHANG H., ZHANG X.Y. Experimental study on $\mathrm{SO}_{2}$ recovery using a sodiumzinc sorbent based flue gas desulfurization technology. Chinese J Chem Eng 23, 241, 2015.

22. XUE N.T., WANG L., ZHENG T.L., WANG J.H., WANG Q.H. Biodegradation of sulfite in flue gas absorbent byusing a biotrickling filter at anaerobic condition. Process Saf Environ 98, 399, 2015.

23. BIAN J.J., ZHANG Q., MIN X., ZHANG S., FENG L.J., LI C.H. Modified clinoptilolite catalysts for seawater flue gas desulfurization application: Preparation, characterization and kinetic evaluation. Process Saf Environ 101, 117, 2016

24. ZHANG Y., GUO S.Y,, ZHOU J.T., LI C.Y., WANG G.D. Flue gas desulfurization by $\mathrm{FeSO}_{4}$ solutions and coagulation performance of the polymeric ferric sulfate by-product. Chem Eng Process: Process Intensification 49, $859,2010$.
25. YE W.Q., LI Y.J., KONG L., REN M.M., HAN Q. Feasibility of flue-gas desulfurization by manganese oxides. Trans Nonferrous Met Soc China 23, 3089, 2013.

26. CHEN Z., DONG H., YU H.B., YU H. In-situ electrochemical flue gas desulfurization via carbon blackbased gas diffusion electrodes: Performance, kinetics and mechanism. Chem Eng J 307, 553, 2017.

27. DING S., LI Y.R., ZHU T.Y., GUO Y.Y. Regeneration performance and carbon consumption of semi-coke and activated coke for $\mathrm{SO}_{2}$ and $\mathrm{NO}$ removal. J Env Sci 34, 37 2015.

28. HAO R.L., ZHANG Y.Y., WANG Z.Y., LI Y.P., YUAN B., MAO X.Z., ZHAO Y. An advanced wet method for simultaneous removal of $\mathrm{SO}_{2}$ and $\mathrm{NO}$ from coal-fired flue gas by utilizing a complex absorbent. Chem Eng J 307, 562, 2017.

29. EFTHIMIADOU A., NIKOLAIDES I.P., TOURLIDAKIS A. A proposal for $\mathrm{SO}_{2}$ abatement in existing power plants using rich in calcium lignite. Appl Therm Eng 74, 119, 2015.

30. GREEN J.B., MANAHAN S.E. Adsorption of sulphur dioxide by sodium humates. Fuel 60, 488, 1981.

31. LI Y.T., YI H.H., TANG X.L., LIU X., WANG Y.E., CUI B.C., ZHAO S.Z. Study on the performance of simultaneous desulfurization and denitrification of $\mathrm{Fe}_{3} \mathrm{O}_{4}-\mathrm{TiO}_{2}$ composites. Chem Eng Journal 304, 89, 2016.

32. WEI Z.S., LIN Z.H., NIU H.J.Y., HE H.M., JI Y.F. Simultaneous desulfurization and denitrification by microwave reactor with ammonium bicarbonate and zeolite. J Hazard Mater 162, 837, 2009.

33. YAO X., XIE Q.,YANG C., ZHANG B., WAN C.R., CUI S.S. Additivity of pore structural parameters of granular activated carbons derived from different coals and their blends. Int J Min Sci Techno 26, 661, 2016.

34. LI H.Q., ZHANG X.L., LI X.D. Research development of flue gas desulfuration and denitrifictation integration technology. Electr Power Environ Protec 30, 14, 2014.

35. SHA G.F. Research progress of technology for desulfurization and Denitrification of fire-coal flue gas. Chem Res 24, 315, 2014.

36. LI C.J., ZHAO R., PENG M.Q., LIU H., YU G., XIA D.S. Study on desulfurization and denitrification by modified activated carbon fibers with visible-light photocatalysis. J Fuel Chem Technol 43, 1516, 2015.

37. GUO S.P. Research on Ammonia-Based Wet Flue Gas Desulfurization and Simultaneous Desulfurization and Denitrification Combined with Ozone Oxidation. East China University of Science and Technology, Shanghai, China, 2015.

38. LIEMANS I., ALBAN B., TRANIER J.P., THOMAS D. $\mathrm{SO}_{\mathrm{x}}$ and $\mathrm{NO}_{\mathrm{x}}$ absorption based removal into acidic conditions for the flue gas treatment in oxy-fuel combustion. Energy Procedia 4, 2847, 2011.

39. WANG J., ZHONG W.Q. Simultaneous desulfurization and denitrification of sintering flue gas via composite absorbent. Chinese J Chem Eng 24, 1104, 2016.

40. DING, J., QIN, Z., ZHANG, S.L. Simultaneous desulfurization and denitrification of flue gas by catalytic ozonation over Ce-Ti catalyst. Fuel Process Technol 128, 449, 2014

41. DING J., CAI H., QIN Z., LIN J.D., XIAO J.J., ZHANG S.L., FAN M.H. Selective denitrification of flue gas by $\mathrm{O}_{3}$ and ethanol mixtures in aduct: Investigation of processes and mechanisms. J Hazard Mater 311, 218, 2016.

42. MA S.M., ZHAO Y.C., YANG J.P., ZHANG S.B., ZHANG J.Y., ZHENG C.G. Research progress of pollutants removal 
from coal-fired flue gasusing non-thermal plasma. Renew Sust Energy Rev 67, 791, 2017.

43. TONG W. Study on the Combined Desulfurization and Denitriflcation Base on Circulating Fluidized Bed Process. Lanzhou University, Lanzhou, China, 2012.
44. FAN Z.L., YUN H.F., LI G.X., YUAN Q.G., LI M.C. Research Progress in Simultaneous Desulfurization and Denitrification Technologies for Flue Gas. Contemp Chem Indy 43, 2057, 2014. 